Maurer School of Law: Indiana University

Digital Repository @ Maurer Law

1970

\title{
The Nonproliferation Treaty and Peaceful Uses of Nuclear Explosives
}

Thomas Ehrlich

Indiana University School of Law

Follow this and additional works at: https://www.repository.law.indiana.edu/facpub

Part of the Diplomatic History Commons, International Relations Commons, and the Military, War, and Peace Commons

\section{Recommended Citation}

Ehrlich, Thomas, "The Nonproliferation Treaty and Peaceful Uses of Nuclear Explosives" (1970). Articles by Maurer Faculty. 1765.

https://www.repository.law.indiana.edu/facpub/1765

This Article is brought to you for free and open access by the Faculty Scholarship at Digital Repository @ Maurer Law. It has been accepted for inclusion in Articles by Maurer Faculty by an authorized administrator of Digital Repository @ Maurer Law. For more information, please contact rvaughan@indiana.edu.

\section{$\Psi$}

LAW LIBRARY

INDIANA UNIVERSITY

Maurer School of Law
Bloomington 


\section{THE NONPROLIFERATION TREATY AND PEACEFUL USES OF NUCLEAR EXPLOSIVES}

\section{Thomas Ebrlich*}

$\mathbf{I}^{\mathrm{N}}$ $\mathrm{N}$ the past, nuclear arms control and peaceful uses of nuclear explosives were seen by many as competing, if not opposing, interests. At one extreme, some viewed peaceful uses as an annoying irritant on the way to general and complete disarmament. ${ }^{1}$ At the other extreme, some considered arms-control arrangements, particularly those limiting nuclear testing, as bothersome barriers to realizing the full benefits of peaceful nuclear explosions. ${ }^{2}$ Most found themselves somewhere between the two extremes; but most also sensed a continuing tension between essentially opposing forces.

In my judgment, the 1968 Treaty on the Nonproliferation of Nuclear Weapons ${ }^{3}$ has altered this polarity, and the future use of nuclear explosives for peaceful purposes will depend in large measure upon the international arrangements for arms control that are developed under

- Professor of Law, Stanford University School of Law. A.B., 1956, LL.B., 1959, Harvard University.

This Article is adopted from a paper presented to a conference on Engineering with Nuclear Explosives, sponsored by the American Nuclear Society and the Atomic Energy Commission, and held in Las Vegas, Nevada, in January 1970. The conference papers are being published by the Atomic Energy Commission.

My thanks are due to Professors John Barton and Wolfgang Panofsky for helpful comments on the paper during its preparation.

1 For an example of concern about the impact of peaceful-uses programs on armscontrol arrangements, see the testimony of Dr. H.D. Smyth in Hearings on Frontiers in Atomic Energy Research Before the Subcomm. on Research and Development of the Joint Comm. on Atomic Energy, 86th Cong., 2d Sess. 14 (1960).

2 This sentiment is harder to document, but it has sometimes emerged in my discussions with individuals active in the Plowshare Program. Cf. Koop, Plowshare and the Nonproliferation Treaty, 12 ORBIs 793, 806-07 (1968).

3 For the text of the treaty and a full analysis of its legal imphications, see M. WILLrich, Non-Proliferation Treaty: Framiework for Nuclear Arms Control (1969). A briefer treatment may be found in Firmage, The Treaty on the Non-Proliferation of Nuclear Weapons, 63 AM. J. INT'L L. 711 (1969). See also Koop, supra note 2; Note, The Nonproliferation Treaty and Peaceful Applications of Nuclear Explosions, 20 Sran. L. Rev. 1030 (1968).

For a step-by-step account of the treaty negotiations from a United States perspective, and for the text of many relevant documents, see U.S. ARMs ConTrol AND Disarmament Agency, Dep't of State, International Negotiations on the Treaty of the Nonproliferation of Nuclear Weapons (1969). 
this treaty. I also believe that the success of the treaty in checking the proliferation of nuclear weapons is contingent, in substantial part, on those peaceful-uses arrangements. Areas of conflict still exist between the active development of peaceful uses for nuclear explosives and nuclear arms control. But the treaty has established new and important ways in which arms control and peaceful uses complement each other and must develop together.

The treaty is primarily a security measure, aimed at reducing the risk of nuclear war by rendering permanent the current separation between nuclear-weapon powers and non-nuclear-weapon nations. Each nuclearweapon state agrees not to transfer nuclear weapons or other nuclear explosive devices to any recipient, and each non-nuclear-weapon country agrees not to accept such devices. The non-nuclear-weapon parties also undertake to negotiate safeguards agreements with the International Atomic Energy Agency (IAEA) covering peaceful-uses activities. All signatories agree not to transfer fissionable material to nonnuclear-weapon countries unless they have become subject to such an agreement. ${ }^{4}$ These provisions are part of a scheme to limit the likelihood that the existing nuclear oligopoly will be broken. They impose positive obligations on the non-nuclear-weapon states without imposing any corresponding burdens upon the nuclear powers. The nuclear powers, however, make two substantial commitments under the treaty. First, they are bound by Article VI to "pursue negotiations in good faith on effective measures relating to cessation of the nuclear arms race at an early date." Second, the nuclear-weapon states promise in Article $\mathrm{V}$ to ensure that the "potential benefits of any peaceful applications of nuclear explosions will be made available" to non-nuclear nations.

Among the five nuclear powers, the United States, the Soviet Union and the United Kingdom have ratified the treaty. France has declared that it will not sign, but says that it welcomes the agreement and will abide by its terms. The Peoples Republic of China has also refused to

4 Like numerous international agreements, the treaty raises almost as many questions as it resolves-perhaps more. A range of the issues concerning nuclear safeguards arrangements with the IAEA, and the role of EURATOM in such arrangements, remain to be settled. See Scheinman, Nuclear Safeguards, the Peaceful Atom, and the IAEA, INr'L Conciliation No. 572 (March 1969). A cluster of problems also relates to peacefuluses research, and particularly to fission-free explosive research. See Van Cleave, The Nonproliferation Treaty and Fission-Free Explosive Research, 11 OnBrs 1055 (1968). This Article focuses, however, upon the actual use of nuclear explosives for peaceful purposes and the international arrangements concerning such uses that are called for under the treaty. Even in that area, it is not possible to do more than suggest answers to some of the principal questions involved. 
join, but it has given no indication that it will encourage nuclear proliferation. Although the United States and the Soviet Union were the principal negotiators and sponsors of the treaty, they delayed ratification until December 1969. As now appears, the delay was due to the Soviet Union's refusal to ratify until the West German government had signed; the desire to prevent the West German acquisition of nuclear weapons was a principal motivation for Soviet support of the treaty. The United States, in turn, withheld its ratification until Soviet approval was assured. On March 5, 1970, the treaty went into effect. On that date, 97 nations had signed the agreement, and 47 had ratified it. ${ }^{5}$

Although the treaty is now in effect, it is by no means certain that it will succeed in checking the proliferation of nuclear-weapon states. Success requires that the "near-nuclear" or "threshold" nations abide by its terms. At least seven nations apparently have the capacity to produce nuclear weapons and delivery systems within five to ten years after a decision to do so. More than a dozen others are not far behind. ${ }^{\circ}$ Four of the threshold states, India, Israel, Japan and West Germany, believe they have serious security problems for which nuclear weapons are a plausible solution. Of these four, only West Germany and Japan have signed the treaty, and both governments have indicated that they will not ratify until adequate safegnards arrangements are negotiated. ${ }^{\top}$

The near-nuclear nations, especially the four that perceive national security problems, are crucial to the success of the treaty. As each one of them delays, others may hesitate as well. Pakistan probably will not ratify the treaty unless India is a party; some African states may abstain until South Africa joins; Arab states will presumably refuse to ratify without a commitment from Israel; Brazil is holding back; will other South American counties sign without her? Time will be critical in each threshold nation's process of deciding on ratification. In several cases, time appears to be running out.

What pressures may induce at least most of the threshold states to

5 N.Y. Times, Mar. 6, 1970, at 6, col. 5.

6 Hearings on the Nonproliferation Treaty Before the Senate Comm. on Foreign Relations, 90th Cong., 2d Sess. 31 (1968). The seven countries are Australia, Canada, India, Italy, Japan, Sweden and West Germany. Those that are not far behind are Argentina, Austria, Belgium, Brazil, Chile, Czechoslovakia, Hungary, Israel, Netherlands, Pakistan, Poland, South Africa, Spain, Switzerland, United Arab Republic and Yugoslavia.

7 See German Embassy Press Release, "Government of the Federal Republic of Germany Signs Non-Proliferation Treaty," Nov. 28, 1969; Statement by the Japanese Ambassador to the United States in 62 Dep't State Bull. 228 (1970); N.Y. Times, Nov. 29, 1969, at 1, col. 8. 
conclude that their national interests can be best served by joining the agreement? The United States and the Soviet Union did sponsor a resolution in the United Nations Security Council that sought to give some assurances to non-nuclear-weapon states against nuclear attack. ${ }^{8}$ Much more will depend, however, upon the success of the nuclearweapon parties in fulfilling their two critical obligations under the treaty: arms control and peaceful-uses assistance.

The initial draft of the treaty by the Soviet Union and the United States contained no concrete commitment by nuclear powers to work toward limiting their own nuclear arms. At a Conference of the NonNuclear-Weapon States organized under the auspices of the United Nations in $1968,{ }^{\circ}$ many of those states insisted on the inclusion of an arms limitation commitment, and staked the success of the whole agreement on the honoring of that commitment. Accordingly, Article VI was added to the agreenent to require good faith negotiations on limiting the arms race.

The Strategic Arms Limitation Talks (SALT) between the United States and the Soviet Union began in April of this year. No one can predict whether they will lead to agreement on effective arms control measures, particularly on the crucial questions of deploying Multiple Independently-targeted Re-entry Vehicle (MIRV) and Anti-Ballistic Missile (ABM) systems. It is possible to predict, however, that unless those talks do produce major steps toward Soviet and American arms limitations, the treaty will fail to halt the spread of nuclear weapons. Non-nuclear-weapon states have little incentive to bind themselves to abstinence if nuclear-weapon countries are unwilling to restrict their superior military power. The prime argument in favor of the treaty is an abstract and global one: The proliferation of nuclear powers would certainly create a dangerous world-perhaps destroy it. But within any particular nation the main arguments against signing the treaty are

8 S.C. Res. 255, 1968 Resolutions and Decisions of the Securtty Council. 13, teprinted in U.S. Arms Control and Disarmament Agency, Dep't of State, International Negotiations on the Treaty of the Nonproliferation of Nuclear Weapons 155 (1969).

9 The final document of the conference is U.N. Doc. A/CONF.35/10 (1968). The Conference proceedings are summarized in Gellner, The Conference of Non-NuclearWeapon States, 1968: A Survey of Views and Proposals in Hearings on the Nomproliferation Treaty Before the Senate Comn. on Foreign Relations, 91st Cong., 1st Sess., pt. 2, at 450 (1969). 
usually quite specific and the national dangers that they postulate are difficult to disprove. ${ }^{10}$

Even if the SALT talks do lead to significant bilateral arms-control measures, near-nuclear nations, such as Sweden, demand that the nuclear nations go farther. The Nonproliferation Treaty imposes an international regime of controls on the non-nuclear-weapon nations. Several threshold nations are emphatic that the superpowers must accept a similar regime covering nuclear explosions in all environments. ${ }^{11}$ As part of that arrangement, an international body would pass on all proposals for peaceful-uses explosions, whether by nuclear-weapon or nonnuclear-weapon countries.

Under the 1963 Limited Test Ban Treaty, the nuclear powers are free to conduct underground nuclear explosions that contain resulting radioactive debris within national borders. ${ }^{12}$ Some non-nuclear-weapon nations have argued that only a comprehensive ban would remove the discriminatory features of the current international regime. They claim that nuclear-weapon countries have direct access to major economic and technological benefits that non-nuclear-weapon states can obtain, if at all, only indirectly. ${ }^{13}$ This position has particular significance for projects that raise at least a substantial possibility of spreading radioactive debris beyond national borders. The Indian government and other key threshold states have proposed that any international agreement to authorize such projects should not be made by amending the

10 This argument is forcefully developed in Young, The Control of Proliferation: The 1968 Treaty in Hindsight and Forecast, AdeLPhI PAPERs No. 56 (April 1969).

11 See, e.g., U.N. Doc. A/CONF.35/C.2/SR.10, at 110 (1968).

12 Article I of the treaty reads in part:

1. Each of the Parties to this Treaty undertakes to prohibit, to prevent, and not to carry out any nuclear weapon test explosion, or any other nuclear explosion, at any place under its jurisdiction or control:

(a) in the atmosphere; beyond its limits, including outer space; or underwater, including territorial waters or high seas; or

(b) in any other environment if such explosion causes debris to be present outside the territorial limits of the State under whose jurisdiction or control such explosion is conducted.

Treaty Banning Nuclear Weapon Tests in the Atmosphere, in Outer Space and Under Water, Aug. 5, 1963, art. I, [1963] 2 U.S.T. 1313, T.I.A.S. No. 5433, 480 U.N.T.S. 43.

13 See U.N. Doc. A/CONF.35/C.2/SR.10, at 110 (1968). This pressure by the nonnuclear-weapon states is not an isolated phenomenon. Many are becoming increasingly resentful at what they describe as the combined efforts of the United States and the Soviet Union to maintain monopoly positious in nuclear arms. The recent United Nations General Assembly rejection of the seabed agreement negotiated by the two superpowers is another example. See N.Y. Times, Dec. 16, 1969, at 8, col. 8; id., Dec. 1, 1969, at 6, col. 1 . 
Limited Test Ban Treaty, but rather through a comprehensive ban and a separately negotiated agreement establishing an international regime to regulate all nuclear explosions. ${ }^{14}$

In the eyes of many non-nuclear-weapon states, a comprehensive ban is thus a link between arms control and peaceful uses-two major aspects of the quid pro quo demanded by those states in exchange for adherence to the Nonproliferation Treaty. Along with arms-control measures, they insist that the nuclear-weapon powers carry out their obligation to share the peaceful benefits of nuclear explosives. The representative of Afghanistan to the Conference of Non-NuclearWeapon States argued, for example, that "the fate of the treaty . . . would depend not only on the adoption of specific disarmament measures by the nuclear-weapon Powers, but also on the speed with which they fulfilled their obligation under the treaty to contribute to the further development of the peaceful uses of nuclear energy." 15 The non-nuclearweapon states did not present a unted front on the scope of this obligation, any more than on other questions. Their interests differed, particularly in relation to their levels of industrialization. Threshold countries, such as Canada, were concerned primarily that they might be foreclosed from competing in the non-military nuclear field. Developing nations concentrated on exacting maximum benefits for their own economic growth. ${ }^{16}$ The representative from Peru, for example, claimed that the "main use of nuclear energy should be to accelerate the development of countries and regions faced with problems that could not be solved by conventional methods. Injustices of any kind which divided the countries of the international community should be eliminated." 17 All of the non-nuclear-weapon nations seem to agree that the commitment of the nuclear parties to assist other signatories in exploiting the peaceful benefits of nuclear explosives offers a major opportunity both for rapid

14 See U.N. Doc. A/CONF.35/C.2/SR.12, at 129 (1968). The perceived relationship between a comprehensive ban and peaceful uses of nuclear explosives, at least insofar as many countries are concerned, may be found in Resolution L, adopted by the Conference of Non-Nuclear-Weapon States. U.N. Doc. A/CONF.35/10, at 18-19 (1968).

15 U.N. Doc. A/CONE.35/C.2/SR.9, at 97 (1968).

16 For a study of the differing positions held by non-nuclear-weapon states, see Scheinman, supra note 4 , at 30-33.

17 U.N. Doc. A/CONF.35/C.2/SR.12, at 131 (1968). A representative of the U.A.R. put the point more sharply. He said that developing nations want to avoid being "turned into a nuclear market comparable to the old semi-colomial markets, in the sense that those countries would supply nuclear raw materials to the advanced States, from which they would acquire finished industrial products ...." U.N. Doc. A/CONF. 35/C.2/SR.7, at 66 (1968). 
expansion of peaceful-uses development and for a major contribution to the success of the Nonproliferation Treaty. What is that commitment and how is it to be met?

Article $V$ of the treaty provides:

Each Party of the Treaty undertakes to take appropriate measures to ensure that ... under appropriate international observation and through appropriate international procedures, potential benefits from any peaceful applications of nuclear explosions will be made available to non-nuclear-weapon States Party to the Treaty on a non-discriminatory basis and that the charge ... will be as low as possible.

The first United States-Soviet draft of the agreement included only a general reference to peaceful uses in the preamble. ${ }^{18}$ The two superpowers favored a separate agreement on the subject. India and Brazil, however, opposed any prohibition against the possession and use of nuclear devices for peaceful purposes. They wanted an exemption for peaceful-uses explosives along the lines of the agreement establishing a Latin American Nuclear-Free Zone. ${ }^{19}$ Other non-nuclear-weapon nations, though recognizing that the similarity between military and non-military nuclear technology requires a total ban, insisted on specific treaty langnage to ensure that they would participate in the benefits of peaceful uses. In fact, the debate at the Conference of the Non-Nuclear-Weapon States made it clear that many countries have quite unrealistic expectations of the benefits to their countries of peaceful-uses explosives. The very hesitancy of the United States and the Soviet Union in agreeing to Article V seems to have spurred on some non-nuclear-weapon countries in their vision of possible benefits. Brazil, for example, has suggested linking the Amazon and the Rio de La Plata by nuclear explosion. ${ }^{20}$ Bolivia has proposed exploitation of its mineral

18 U.S. Arms Controt and Disarmament Agency, Dep't of State, Documents on Disarmament 338-39 (1967) [hereinafter cited as Documents on Disarmamenr]. The first agreed United States-Soviet Union draft was submitted on August 24, 1967. For a history of the subsequent revisions, see U.S. ARMS Control AND Disarmament Agency, Dep't of State, International Negotiations on the Treaty of the Nonproliferation of Nuclear Weapons 98-124 (1969).

19 For the text of the Treaty for the Prohibition of Nuclear Weapons in Latin America (Treaty of Tlateloco), see U.N. Doc. A/C.1/946 (1967); M. Wrurrich, supra note 3, at 201. The United States and the United Kingdom both signed Protocol II to the Treaty, thereby undertaking not to use or threaten to use nuclear weapons against the parties.

20 Koop, supra note 2, at 809 . 
resources. ${ }^{21}$ The threshold nations have been more cautious; their projjects include the Australian harbor proposal and oil and gas development in Canada. Other proposals, particularly from the least developed nations, seem to bear little resemblance to reality. ${ }^{22} \mathrm{My}$ point, however, is not to weigh the relative merits of alternative proposals, but to emphasize the intensity of feeling, particularly among developing countries, that the nuclear powers must provide substantial peaceful-uses assistance. In considering these pressures, the United States may have to reconcile conflicts between the commercial interests of American private firms in the nuclear field and American foreign policy interests in carrying out obligations under Article $V .^{23}$

Article $V$ provides that the benefits of peaceful applications shall be offered "pursuant to a special international agreement or agreements, through an appropriate international body with adequate representation of non-nuclear-weapon States." Bilateral agreements are recognized as an alternate method for transferring the benefits of peaceful uses, although several nations opposed this reference on the ground that multilateral control is essential to prevent discrimination. Bilateral accords will certainly be necessary for any specific project, but all countries now seem to agree that multinational machinery is needed to carry out the mandate of Article V.

Whatever arrangements are made under Article $V$, each nuclearweapon party will insist that any nuclear device it provides for a peaceful-uses explosion must remain under its supervision at all times because Article I forbids any transfer of "control" over a nuclear device to "any recipient whatsoever." But any provision of nuclear explosions for peaceful uses must take place under "appropriate international observation and through appropriate international procedures." Article V provides that negotiations on the "special international agreement or agreements" are to begin as soon as possible after the treaty enters into force. It seems likely, however, that a number of key nations will not ratify the treaty-and thus limit their bargaining power-unless they are assured of a satisfactory outcome of the negotiations. The Eighteen $\mathrm{Na}$ tion Disarmament Conference will probably provide a principal forum, though a good deal of private consultation will also be needed. ${ }^{24}$

21 U.N. Doc. A/CONF.35/C.2/SR.9, at 98 (1968).

22 For a discussion of the potential benefits of peaceful nuclear technology for developing countries, see U.N. Doc. A/7568 (1968).

23 See Young, supra note 10, at 15.

24 In 1961, the United Nations General Assembly unanimously endorsed an agreement between the United States and the Soviet Union establishing the Eighteen Na- 
The treaty provides no detailed guidance for ensuring that nuclearweapon states will carry out their obligations under Article $V$ to share the benefits of peaceful nuclear explosions on a non-discriminatory basis and at the lowest possible cost. It would undermine the treaty purposes if each nuclear-weapon state were to decide on a wholly unilateral basis the extent to which it would contribute. At the same time, it seems equally improper to conclude that a non-nuclear-weapon state has a legal claim against the United States, for exanple, for any and all information, material or other assistance desired. As a practical matter, this problem may be more apparent than real, since the nuclearweapon states must realize that their willingness to neet their commitments under Article $V$ is a critical elenent in the success of the treaty.

It is entirely possible, however, that no nuclear-weapon country will wish to assist some nations-South Africa, for exaniple-in the development of their mineral resources. Is refusal on foreign-policy grounds precluded by the requirement that peaceful-uses services be offered on a "non-discriminatory" basis? United States representatives have stated that they anticipate no shortage of nuclear explosive devices for peaceful uses. ${ }^{25}$ They have also committed the United States to arrangenients under Article $V$ that will "make clear that, once the participating nuclear Powers are prepared to undertake practical apphications of peaceful nuclear explosives, they will not withhold nuclear detonation services to others because of extraneous considerations." ${ }^{26}$ But what about a Cuban request to develop a new harbor with nuclear explosives? The Senate Foreign Relations Committee, in its favorable report on the treaty, stated that it "specifically rejects any suggestion that Article $V$ constitutes an across-the-board pledge by the United States to support foreign . . . projects." 27 In the eyes of many nations, however, that is precisely the pledge made by the United States.

Another problenı may arise if two nuclear-weapon parties are willing to conduct a peaceful nuclear explosion in a particular country. Canada, among others, has urged that "the international body" designated under Article $V$ not be placed in the position of having to designate a particular supplier, but instead that the decision should be left to the requesting state. ${ }^{28}$ Sweden, on the other hand, has suggested that

tion Disarmament Conference. 16 U.N. GAOR 1129, U.N. Doc. A/RES/1722 (XVI) (1962).

25 U.N. Doc. A/7678, at 39 (1969).

26 Documients on Disaratament 173.

27 S. ExEc. Rep. No. 9, 90th Cong., 2d Sess. 14 (1968).

28 U.N. Doc. A/7678, at 13 (1969). 
nuclear-explosive 'devices "might be committed to a formal 'pool' for allocation, by this body, to interested customers." 29

From the outset of the treaty negotiations, the United States and the Soviet Union have urged that the IAEA assume the duties of the "international body" referred to in Article V. ${ }^{30}$ The United Nations Secretary General and the Agency's Board of Governors concur. ${ }^{31}$. This judgment is based mainly upon the technical competence of the Agency and the broad terms of its enabling legislation. The Agency has authority to "encourage and assist research on, and development and practical application of, atomic energy for peaceful uses throughout the world; and, if requested to do so, to act as an intermediary for the purposes of securing the performance of services or the supplying of materials, equipment, or facilities by one member of the Agency for another." 32

Although a great majority of countries support the Soviet-American view that the IAEA should be the "international body" of Article $V$, a number of non-nuclear-weapon states, particularly among the developing nations, contend that the IAEA Board is dominated by nuclearweapon powers and their allies. These nations call for a major restructuring of the Board to give them a stronger voice in governing the Agency. ${ }^{33}$ The Board will probably undergo some reorganization to increase the representation of the non-nuclear-weapon nations. Some nations, lowever, have called for a special body within the agency or a wholly separate entity. ${ }^{34}$ It was apparently in response to such demands that Article $\mathrm{V}$ was drafted without specific mention of the Agency; Article III on safeguards arrangements refers to it explicitly. Similar considerations help to explain the requirement that the "international body" have "adequate representation" of the non-nuclearweapon states. In all events, those states are united in the view that in

29 Documents on Disarmament 248, 250.

30 For a summary of the national views and the position of the Board of Governors of the IAEA and the Secretary General of the United Nations on the "international body," see U.N. Doc. A/7678 (1969).

31 U.N. Doc. A/7678, at 6, 46 (1969).

32 Statute of the International Atomic Energy Agency, Oct. 26, 1956, art. III.A.1, [1957] 1 U.S.T. 1093, T.I.A.S. No. 3873, 276 U.N.T.S. 3.

33 E.g., U.N. Doc. A/CONF.35/C.2/SR.9, at 100 (remarks of the Representatives of Pakistan). See Scheinman, supra note 4, at 18-19. (IAEA is "balanced politically, geographically, economically, and technologically so as to give an edge to the nuclear powers and the Western states").

34 E.g., U.N. Doc. A/CONF.35/C.2/SR.5, at 39-41 (remarks of the Representative from Ghana). 
the 1970's the nuclear-weapon powers have a primary obligation to develop their peaceful-uses technology, to provide assistance when requested, and in the interim to help establish the necessary international machinery.

It may well be that different institutions will be assigned different responsibilities under Article V. Consider the range of those responsibilities. A clearinghouse should be established to screen projects proposed by the non-nuclear-weapon states for submission to nations able to supply the services. Conceivably, this clearinghouse could also conduct proposal feasibility studies. The IAEA seems well suited to undertake these functions because of its extensive experience in related fields. The Agency has in the past conducted large-scale studies of economic, technical and safety aspects of reactor proposals and has assisted in a study of the health and safety aspects of using nuclear explosives in Panama. Article $V$ also calls for "appropriate international observation," a function similarly suited to the IAEA, even though the details of "observation" will be difficult to resolve. Most important, what steps will be taken to assure that a nuclear device will remain under the control of the nuclear-wveapon state that supplies it and that the project is solely for peaceful purposes?

The problems in working out these steps expose possible areas of future conflict between arms control and peaceful uses. The most effective employment of nuclear explosives for excavation projects will require device-development tests as well as application tests of existing devices. Without development tests, the full economic potential of nuclear excavation will not be realized. Yet complete access to a device is apparently needed to determine whether its development is primarily for peaceful or for military purposes; such access might be unacceptable to either the United States or the Soviet Union..$^{35}$ At the least, it would be extremely difficult to specify the conditions for carrying out peaceful-uses development tests with sufficient precision to exclude opportunities for weapons development. Technical advances are always possible in this field, as in others, but at the current stage of nuclear technology, these problems raise serious arms-control hurdles for excavation projects. Under the Limited Test Ban Treaty, the problems are restricted to excavation projects that spread radioactive debris beyond national borders. Under a comprehensive ban, however, all excavation projects would be affected.

35 In all events, such access would require new United States legislation. See 42 U.S.C. 52164 (1964). 
Extractive projects do not require further device development, at least to the same degree as excavation proposals. But those projects would raise other arms control complications in the event of a comprehensive test ban agreement. In response to a request that a nuclearweapon nation explode a device for an extractive project, that nation might secretly use-and thus test-a device designed for weapons purposes. It may be possible to avoid the problem by, for example, an international warehouse, but the necessary arrangements would require complex planning.

Questions may also arise whether particular nuclear explosion services are offered at the lowest possible cost, excluding any charge for research and development. The "international agreement" referred to in Article $\mathrm{V}$ will probably place the task of defining costs with the IAEA, but it is possible that a new body, or at least a new mechanism within the Agency, will be established. Currently, the Agency Board is illequipped to act as a dispute-settlement institution, particularly outside of the limited areas of its current duties. An ad hoc or permanent arbiter of the type developed under other international agreements may offer a promising alternative. ${ }^{36}$

The most likely area for creating an international institution apart from the IAEA is the settlement of alleged conflicts between the Nonproliferation Treaty and the Limited Test Ban Treaty. One interpretation of the 1963 treaty is that no nation may conduct any nuclear explosion on the territory of another nation, since such an explosion would take place "outside the territorial limits of the State under whose jurisdiction or control such explosion is conducted." ${ }^{37}$ When coupled with the requirement that nuclear devices remain in the custody of nuclearweapon states, this view would prevent the signatories of the 1963 treaty from carrying out their obligations under Article $V$ of the Nonproliferation Treaty. But such a literal interpretation seems inconsistent with the intent of the framers of both agreements. Nonetheless, conflicts may arise, and some machinery will be needed to resolve them.

36 The mechanisms established for the International Consortium for Satellite Communications and the International Coffee Agreenient are two examples. See 1 A. Chaxes, T. Ehrlich, \& A. Lowenfeid, International Legal Process 576-704 (1968).

37 Treaty Banning Nuclear Weapon Tests in the Atmosphere, in Outer Space and Under Water, Aug. 5, 1963, art. I, $\$ 1$ (b), [1963] 2 U.S.T. 1313, T.I.A.S. No. 5433, 480 U.N.T.S. 43. See text of Article I at note 12 supra. For an analysis of the Limited Test Ban Treaty, see Ehrlich, The 1963 Nuclear Test Ban Treaty and Civil Nuclear Engineering, in Education for Peaceful Uses of Nuclear Explosives 223 (WWeaver ed. 1970). 
Suppose, for example, that Iran calls on the Soviet Union to explode a particular nuclear device in Iran for purposes of oil development, and the Soviet Union claims that the explosion would violate its obligations under the 1963 treaty. The non-nuclear-weapon states will probably insist upon some multilateral dispute-settlenient mechanism to avoid unilateral decisions by the nuclear powers. Further, the mechanism will probably be demanded before agreement to any peacefuluses explosions, such as a trans-isthmian canal, ${ }^{38}$ that "cause radioactive debris to be present" beyond national borders. The same issues will arise if the limited ban is supplanted by a more conprehensive treaty.

What type of institution is suitable for making decisions under the Limited Test Ban Treaty (or a comprehensive ban) concerning the risks of a particular peaceful project? A nunber of nations such as Mexico have stated that these questions should be resolved under United Nations jurisdiction, although in close cooperation with the "international body" estabhished under Article V. ${ }^{39}$ But much may depend on the standards to be applied. If, for example, health hazards become the primary concern, then the World Health Organization is a possible candidate. In any case, some new fact-finding and adjudicatory entity may be needed to apply the negotiated standards to specific cases.

The United States and the Soviet Union could well benefit from nuultilateral resolution of these issues. Multilateral arrangements would avoid the need for each superpower to impose its own standards in the face of political pressures from nations seeking assistance. Those arrangements might also reduce public fears of the risks involved with peaceful nuclear explosions. ${ }^{40}$ In addition, much can be gained from allocating the decision-nuaking functions to an institution that is not on the front lines of political controversy, so that the decisions may be viewed, insofar as possible, as technical ones. The more technical and less political a decision, however, the greater the need for precisely drafted standards, and experience indicates that agreement within the international scientific community on the health dangers of radioactive fallout is unlikely.

Other areas of alleged conflict may also arise, apart from issues of standards. Whatever the mechanism chosen, what will be the scope of its jurisdiction, and will that jurisdiction be compulsory? Will the

${ }^{38}$ Hearings on the Nuclear Test Ban Treaty Before the Senate Comm. on Foreign Relations, 88th Cong., 1st Sess. 210 (1963).

39 U.N. Doc. A/7678, at 28 (1969).

$40 \mathrm{M}$. WIILRICH, supra note 3 , at $145-46$. 
institution's decisions be binding or advisory, and will it be a permanent board or an ad hoc panel established for each decision? Will the institution review all proposals for peaceful-uses explosions made by non-nuclear-weapon states, or only those rejected by a nuclear power as inconsistent with the 1963 treaty? Will non-nuclear-weapon states be able to seek advance clearance from the institution-a kind of international declaratory judgment-concerning particular proposals? Will third states that object to a peaceful-uses project be authorized to seek a ruling precluding that project-a kind of international injunction procedure? Whatever the standards chosen, will they be waivable and under what circumstances? These are the kinds of questions that may arise in the course of trying to establish the necessary arrangements to deal with this one aspect of the problem.

Until this point, we have been considering the extent of the nuclearweapons states' obligation to provide peaceful-uses services to nonnuclear-weapon nations that are parties to the treaty. Do the nuclear powers also have an obligation not to provide such services to countries that do not ratify? Article $V$ imposes no such requirement explicitly, though a number of nations would apparently support such a provision in the new agreement to be concluded under Article $V .41$ Pakistan went farther, and in a proposal obviously aimed at India, called on nuclear-weapon states to deny all nuclear assistance to states that do not ratify the treaty or negotiate a safeguards agreement with the IAEA. ${ }^{42}$ The long-term interests of the nuclear-weapon states will be served by insisting that nations desiring the peaceful benefits of nuclear explosives be parties to the Nonproliferation Treaty. For some countries, the prospect of those benefits will be a substantial inducement. There is every reason for the nuclear powers to make the most of it.

The Nonproliferation Treaty provides no explicit enforcement mechanisms to handle violations of its terms. Instead, it adopts the scheme developed in the Limited Nuclear Test Ban Treaty of 1963: A party may withdraw "if it decides that extraordinary events, related to the

41 Mexico suggested that the benefits of peaceful nuclear explosives "should be available to all 'States which have renounced nuclear weapons,' where such a renunciation has acquired binding legal force for them under the Treaty or some other contractual instrument-such as, for example, the Treaty for the Prohibition of Nuclear Weapons in Latin America (Treaty of Tlateloco)-providing for an international control system which is at least as effective as, or more effective than, that provided in the above-mentioned Treaty." U.N. Doc. A/7678, at 26 (1969).

42 Scheinman, supra note 4, at 53. 
subject matter of this Treaty, have jeopardized the supreme interests of its country." The 1968 agreement does go beyond the 1963 treaty by requiring not only three-months advance notice, but also notice to the United Nations Security Council and, more important, a statement of the reasons for withdrawal. This provision makes it likely that, apart from withdrawal, enforcement of the Nonproliferation Treaty will be limited to adverse publicity by the IAEA. Other international arrangements might be devised, with ultimate appeal to the Security Council. On issues arising under the treaty, the Council may be able to avoid much of the cold-war standoff that has paralyzed it so often in the past. Hopefully, both the Umited States and the Soviet Union will view their interests in halting nuclear proliferation as outweighing any short-term political gain from involving treaty controversies in cold-war politics.

At the same time, the Nonproliferation Treaty will not stand or fall on the issues of enforcement. The key will be the extent to which the non-nuclear-weapon states find it in their interests to adopt the treaty strictures. In part, resolution of this question by particular nationsand the threshold states are the most important-will turn on matters wholly outside the control of the nuclear-weapon countries. In part, it will turn on the progress made by those countries toward limiting their own nuclear arms. But a critical element in the decision of many nonnuclear-weapon states will be whether they conclude that they can gain substantial benefits from peaceful nuclear explosives by joining the agreement.

For perhaps the first time, non-nuclear nations have some leverage in nuclear affairs. They are no longer content with peaceful coexistence by the superpowers. They demand that American and Soviet resources now allocated to nuclear arms be used to help meet their development needs. Far from being mutually exclusive, therefore, arms control and peaceful uses reinforce each other in this area, and they must develop in conjunction. The United States can take advantage of the opportunity by a major expansion of its Plowshare Program, particularly directed at helping other nations. 